\title{
Pengembangan Media Pembelajaran Animasi Dengan Nuansa Kemaritiman Berbantuan Macromedia Flash 8 pada Materi Relasi Kelas VIII SMP
}

\author{
Jayanti Natasya ${ }^{1}$, Nur Izzati ${ }^{2 *}$ \\ ${ }^{12}$ Universitas Maritim Raja Ali Haji, Tanjungpinang, Provinsi Kepulauan Riau, Indonesia \\ Pengiriman: 31/Januari/2020; Diterima: 24/Maret/2020; Publikasi: 31/Maret/2020 \\ DOI: https://doi.org/10.31629/jg.v5i1.1948
}

\begin{abstract}
Abstrak
Uji coba implementasi kurikulum kemaritiman (pilot project) di sekolah-sekolah telah mulai dilakukan sehingga perlu adanya media pembelajaran yang berbasis kemaritiman. Penelitian ini bertujuan untuk mengembangkan media pembelajaran animasi dengan nuansa kemaritiman berbantuan Macromedia Flash 8 pada materi relasi kelas VIII SMP. Jenis penelitian ini adalah Research and Development dengan menerapkan model 4D melalui empat tahapan yaitu define, design, development, dan disseminate. Penelitian ini melibatkan 26 peserta didik kelas VIII C SMP Negeri 3 Bintan. Data penelitian ini dikumpulkan melalui teknik validasi yang dilakukan oleh validator ahli dan angket respon peserta didik untuk mengukur tingkat kelayakan media pembelajaran. Instrumen yang digunakan dalam penelitian berupa lembar validasi media, lembar validasi materi, dan lembar angket respon peserta didik. Teknik analisis data menggunakan Method of Summated Ratings, kemudian dihitung persentase kelayakan media yang dikembangkan. Hasil penelitian menunjukkan persentase kelayakan ahli media sebesar 91,25\%, ahli materi 97,38\%, serta dari angket respon peserta didik $88,74 \%$, ketiga hasil penilaian tersebut termasuk dalam kategori sangat layak. Sehingga dapat disimpulkan bahwa media yang dikembangkan sangat layak digunakan.
\end{abstract}

Kata kunci: pengembangan; media animasi; macromedia flash 8; relasi; kemaritiman

\begin{abstract}
Trial implementation of the maritime curriculum (pilot project) in schools has begun to be carried out so there is a need for maritime-based learning media. This study aims to develop animation learning media with maritime nuances aided by Macromedia Flash 8 on grade VIII junior high school relations material. This type of research is Research and Development by applying the 4D model through four stages namely define, design, development, and disseminate. This study involved 26 students of class VIII C of SMP Negeri 3 Bintan. The data of this study were collected through validation techniques conducted by expert validators and student questionnaire responses to measure the feasibility of learning media. The instruments used in the study were media validation sheets, material validation sheets, and student response questionnaire sheets. The data analysis technique uses the Method of Summated Ratings, then the percentage of feasibility of the media developed is calculated. The results showed the percentage of eligibility of media experts was $91.25 \%$, material experts $97.38 \%$, and from the questionnaire responses of students $88.74 \%$, the three results of the assessment were included in the very feasible category. So it can be concluded that the developed media is very feasible to use.
\end{abstract}

Keywords: development; animation media; macromedia flash 8; relation; maritime

*Penulis Korespondensi

Email Address: nurizzati@umrah.acc.id

Handphone : + +62 831-2441-4116 


\section{JURNAL GANTANG. Maret 2020; V(1): 87 - 93 \\ p-ISSN. 2503-0671 \\ e-ISSN. 2548-5547}

\section{Pendahuluan}

Orientasi bangsa Indonesia kembali berfokus pada wilayah perairan dengan segala potensi besarnya. Istilah orang Indonesia tentang "nenek moyang kita seorang pelaut" pada masa lampau kini ingin dibangkitkan kembali (Daris, 2019). Pertama, mengubah land based oriented menjadi maritime based oriented. Mindset kita yang terbiasa berfokus kepada sumber daya di darat harus mulai diarahkan kepada sumber daya di laut karena daerah kita $75 \%$ adalah lautan. Kedua, Indonesia harus memanfaatkan laut baik secara politik maupun ekonomi dan keamanan. Indonesia sebagai negara kepulauan yang kaya akan sumber daya alam memiliki potensi besar untuk menjadi negara yang mandiri, maju, dan kuat dalam bidang kemaritiman. Ketiga, meningkatkan minat dan kesadaran akan potensi kemaritiman Indonesia serta meningkatkan semangat untuk membangun kemaritiman Indonesia (Marsetio, 2018).

Salah satu upaya pemerintah untuk meningkatkan minat dan kesadaran akan potensi kemaritiman adalah melalui pendidikan. Pendidikan merupakan aspek terpenting pada pengembangan suatu negara. Demi memperkuat jati diri bangsa maritim, pendidikan di Indonesia mengimplementasi kurikulum kemaritiman.

Menurut Daris (2019), keseriusan pemerintah begitu tampak dengan terbukti adanya penambahan Kompetensi Dasar pada kurikulum 2013 yang sedang digunakan sekarang mengenai memahami kondisi wilayah Indonesia dan posisi strategisnya sebagai poros maritim dunia. Sejak tahun 2017, Kemenko Maritim telah bekersama dengan Kemendikbud dalam mengembangkan kurikulum kemaritiman dan saat ini telah memasuki uji coba implementasi kurikulum kemaritiman (pilot project) di sekolah-sekolah. Implementasi kemaritiman ini juga pada setiap mata pelajaran, tak terkecuali matematika. Matematika menduduki peran penting dalam dunia pendidikan karena menjadi dasar dan perkembangan ilmu yang lain. Namun, pembelajaran matematika masih dianggap sulit oleh sebagian besar peserta didik. Salah satu materi yang dianggap sulit adalah relasi dan fungsi. Herawati (2014) mengemukakan pada pokok bahasan relasi dan fungsi, peserta didik sulit mendefinisikan konsep relasi dan fungsi, peserta didik kurang memahami akan pemaknaan tahapan dan prosedur materi relasi dan fungsi, juga karena terkendala keterbatasan media pembelajaran disekolah dalam bentuk software pembelajaran matematika interaktif khususnya pada materi relasi dan fungsi. Peserta didik membutuhkan pembelajaran yang inovatif yakni pembelajaran berpusat kepada peserta didik serta media pembeljaaran yang mendukung peserta didik dalam belajar (Rosidah \& Hasanah, 2019). Mengingat pentingnya matematika, maka sangat diharapkan peran seorang guru dapat meningkatkan kualitas pembelajaran

Permendikbud Nomor 65 Tahun 2013 menyatakan bahwa proses pembelajaran pada satuan pendidikan diselenggarakan secara interaktif, inspiratif, menyenangkan, menantang, memotivasi peserta didik untuk berpartisipasi aktif, serta memberikan ruang yang cukup bagi prakarsa, kreativitas, dan kemandirian sesuai dengan bakat, minat dan perkembangan fisik serta psikologis peserta didik. Pembelajaran disekolah saat ini mulai menyesuaikan dengan perkembangan ilmu pengetahuan dan teknologi yang membantu peradaban manusia, sehingga mengakibatkan tuntutan kebutuhan akan pendidikan semakin meningkat dan bervariatif. Hal ini menuntut agar kualitas pendidikan semakin meningkat dan semakin baik. Kebutuhan untuk meningkatkan kualitas pembelajaran sangat penting untuk dapat mengikuti perkembangan ilmu pengetahuan dan teknologi. Dengan adanya peningkatan kualitas pembelajaran, diharapkan dapat meningkatkan minat dan prestasi belajar peserta didik.

Peningkatan kualitas pembelajaran dapat dilakukan melalui penggunaan media pembelajaran yang bervariatif karena dapat mengubah pola pikir dan pandangan peserta didik terhadap matematika. Media Pembelajaran merupakan sarana untuk meningkatkan kegiatan proses belajar mengajar (Kustandi, Sutjipto, 2011 
dalam Muntaha, Budiman, \& Widyaningrum, 2019). Media Pembelajaran yaitu alat yang dapat membantu proses belajar mengajar dan berfungsi untuk memperjelas makna pesan yang disampaikan, sehingga dapat mencapai tujuan pembelajaran dengan lebih baik dan sempurna. Pada tahap orientasi pembelajaran penggunaan media pembelajaran akan sangat membantu keefektifan proses pembelajaran dan penyampaian pesan ataupun isi pelajaran saat itu. Selain mendorong minat dan motivasi peserta didik, media pembelajaran juga dapat membantu peserta didik untuk meningkatkan pemahaman, menyajikan data dengan menarik dan terpercaya, memudahkan penafsiran data dan memadatkan informasi.

Salah satu perangkat lunak untuk membuat media pembelajaran adalah Macromedia Flash 8. Macromedia Flash 8 merupakan salah satu multimedia yang dapat membuat video, animasi, gambar, dan suara dengan cara yang mudah dan efektif. Berdasarkan penelitian oleh Thofan (2018) dengan judul "Pengembangan Media Pembelajaran Animasi Berbasis Macromedia Flash pada Materi Trigonometri”, Macromedia flash 8 merupakan gabungan konsep pembelajaran dengan teknologi audio visual yang mampu menghasilkan fitur-fitur baru yang dapat dimanfaatkan dalam pendidikan. Peserta didik dapat mempelajari materi pelajaran tertentu secara mandiri dengan komputer yang dilengkapi program multimedia.

Dengan menggunakan multimedia, hal yang abstrak dapat dikonkritkan, sehingga dapat ditampilkan ke hadapan siswa dan menarik minat belajarnya. Apabila didalam media pembelajaran memiliki unsur teks, grafik, suara dan animasi dapat terkombinasi dengan baik di dalam suatu media pembelajaran maka akan menghasilkan suatu media pembelajaran interaktif yang menyenangkan. Dengan adanya media pembelajaran ini, diharapkan dapat membantu peserta didik dalam memahami materi matematika khususnya pokok bahasan relasi seiring dengan tuntutan adanya implementasi kemaritiman didalamnya.
Oleh karena itu, peneliti merumuskan masalah dalam penelitian ini adalah bagaimana pengembangan media pembelajaran animasi dengan nuansa kemaritiman berbantuan Macromedia Flash 8 pada materi relasi kelas VIII SMP dan kelayakan media pembelajaran berdasarkan penilaian ahli media, ahli materi dan peserta didik?. Tujuan penelitian ini adalah untuk mendeskripsikan pengembangan media pembelajaran animasi dengan nuansa kemaritiman berbantuan Macromedia Flash 8 pada materi relasi kelas VIII SMP dan kelayakan media pembelajaran berdasarkan penilaian ahli media, ahli materi dan peserta didik.

\section{Metode Penelitian}

Penelitian ini merupakan penelitian pengembangan (Research and Development). Tujuan penelitian ini unuk mengembangkan media pembelajaran animasi dengan nuansa kemaritiman berbantuan Macromedia Flash 8 pada materi relasi kelas VIII SMP.

Penelitian ini mengacu pada model pengembangan 4D yang dikembangkan oleh Thiagarajan. Model ini melalui empat tahapan yaitu define, design, development, dan disseminate (Mulyatiningsih, 2013)

Tahap define (pendefinisian), pada tahap ini sering disebut dengan tahap analisis kebutuhan. Dalam konteks pengembangan media, yang dilakukan pada tahap define diantaranya analisis kurikulum, analisis media pembelajaran, analisis peserta didik, serta analisis konsep. Tahap ini dilakukan untuk menetapkan dan mendefinisikan syarat-syarat pengembangan. Analisis kurikulum, untuk menetapkan pada kompetensi yang mana bahan tersebut akan dikembangkan dalam kurikulum yang berlaku. Analisis media pembelajaran, guna mendapatkan informasi mengenai kebutuhan media pembelajaran serta materi dari mata pelajaran yang akan disajikan. Analisis peserta didik, hal ini penting karena semua proses pembelajaran harus disesuaikan dengan karakteristik peserta didik. Analisis konsep, analisis konsep ialah mengidentifikasi konsep media pembelajaran 


\section{JURNAL GANTANG. Maret 2020; V(1): 87 - 93 \\ p-ISSN. 2503-0671 \\ e-ISSN. 2548-5547}

berbantuan Macromedia Flash 8 berbasis kemaritiman yang dikembangkan sesuai dengan Kompetensi Inti (KI), Komepetensi Dasar, dan Indikator.

Tahap design, kegiatan yang dilakukan pada tahap ini adalah memilih media pembelajaran yang sesuai dengan materi dan peserta didik, serta merancang prototype dari media yang dikembangkan.

Tahap development (pengembangan), kegiatan yang dilakukan adalah memvalidasi kelayakan rancangan produk oleh para ahli, melakukan uji coba, serta melakukan revisi apabila terdapat saran-saran perbaikan dari hasil validasi dan uji coba.

Tahap disseminate (penyebarluasan), tahap ini dilakukan penyebaran produk yang dikembangkan. Karena produk yang dikembangkan dalam bentuk aplikasi, maka penyebaran dilakukan dalam bentuk softcopy.

Subjek uji coba dalam penelitian ini adalah siswa SMP kelas VIII C SMP Negeri 3 Bintan sebanyak 26 orang. Waktu pelaksanaan minggu ketiga bulan November 2019. Data tersebut dikumpulkan melalui metode wawancara tak terstruktur, dan angket. Angket dalam penelitian dan pengembangan media ini diberikan kepada validator dan peserta didik untuk menilai produk pengembangan. Adapun angket yang digunakan adalah angket validasi untuk validator ahli media dan ahli materi serta angket respon peserta didik.

Untuk melihat kevalidan dan kepraktisan media yang dikembangkan maka instrumen yang digunakan pada penelitian terdiri dari lembar validasi dan angket kepraktisan. Lembar validasi meliputi aspek media dan materi. Subaspek pada penilaian validasi media meliputi manfaat media, desain media, dan navigasi/pengoperasian media. Sedangkan subaspek pada penilaian validasi materi terdiri dari kesesuaian tujuan pembelajaran, kualitas materi, penyajian konten materi, dan penyajian self evaluation. Setiap pernyataan pada lembar validasi memuat 5 kategori pilihan penilaian yaitu sangat baik, baik, sedang, tidak baik, dan sangat tidak baik.

Angket kepraktisan terdiri dari 11 pernyataan yang mencakup tentang kepraktisan media. Karena responden angket ini adalah peserta didik maka kategori pilihan penilaian terdiri 4 kategori saja yaitu sangat baik, baik, cukup baik dan kurang baik. Hal ini dimaksudkan agar peserta didik dapat memberikan jawaban dengan yakin.

Teknik analisis data mengacu kepada metode yang dikembangkan oleh Gable yaitu Method of Summated Ratings (MSR). Di mana kategori-kategori respons akan diletakkan pada suatu kontinum, kemudian skor setiap pernyataan ditentukan berdasarkan distribusi respons (Azwar, 2009; Izzati, 2012). Untuk memperoleh persentase kelayakan, maka rumus yang digunakan adalah:

Persentase $=\frac{\text { Jumlah skor hasil validasi }}{\text { Skor tertinggi }} \times 100 \%$

Dari hasil perhitungan tersebut, kriteria interpretasi sebagai berikut:

Tabel 1.

Persentase kelayakan media

\begin{tabular}{cc}
\hline Penilaian & Kriteria Interpretasi \\
\hline $0 \%-20 \%$ & Sangat Tidak Layak \\
$21 \%-40 \%$ & Tidak Layak \\
$41 \%-60 \%$ & Cukup Layak \\
$61 \%-80 \%$ & Layak \\
$81 \%-100 \%$ & Sangat Layak \\
\hline
\end{tabular}

(Riduwan,2013:15 dalam (Fatiris, 2017:8))

Berdasarkan kriteria tersebut, maka media pembelajaran berbantuan Macromedia Flash 8 dapat dikatakan layak apabila semua aspek hasil persentase menunjukkan $\geq 61 \%$.

\section{Hasil dan Pembahasan}

Penelitian ini dilaksanakan di SMP Negeri 3 Bintan dengan subjek uji coba dalam penelitian ini adalah peserta didik kelas VIII C sebanyak 26 orang. Hasil utama dalam penelitian ini adalah Media Pembelajaran Animasi dengan Nuansa Kemaritiman Berbantuan Macromedia Flash 8 pada Materi Relasi Kelas VIII SMP yang layak berdasarkan penilaian ahli materi, ahli media dan peserta didik. Uji coba dilaksanakan minggu ketiga bulan November 2019. Berikut adalah deskripsi tahapan perkembangan produk.

\section{a. Tahap Define}

Tahap ini sering disebut dengan tahap analisis kebutuhan. Tahap ini dilakukan untuk 
menetapkan dan mendefinisikan syarat-syarat pengembangan. Analisis ini dilakukan guna mendapatkan informasi mengenai kebutuhan media pembelajaran serta materi dari mata pelajaran yang akan disajikan. Analisis ini dilakukan dengan melakukan wawancara di SMP Negeri 3 Bintan. Berdasarkan analisis kurikulum, diketahui bahwa kurikulum yang akan digunakan di SMP Negeri 3 Bintan adalah Kurikulum 2013.

Analisis media pembelajaran, analisis media pembelajaran ditujukan guna mengetahui media apa saja yang diterapkan sebelumnya selama proses pembelajaran berlangsung. Dari hasil observasi dan wawancara yang dilakukan di SMP Negeri 3 Bintan tentang kebutuhan media untuk mata pelajaran matematika, didapatkan informasi bahwa media pembelajaran yang tersedia tergantung pada kreativitas guru. Ketersediaan media masih minim terutama untuk media pembelajaran berbasis IT. Media yang masih digunakan ialah buku cetak yang telah disediakan oleh sekolah. Media pembelajaran berbasis IT yang digunakan guru matematika tersebut hanya Geogebra. Geogebra ini adalah aplikasi yang membantu dalam materi persamaan garis. Untuk materi lainnya seperti relasi, guru masih menjelaskan secara konvensional yaitu menjelaskan melalui media papan tulis. Oleh sebab itu, diperlukan media pembelajaran yang menarik guna menunjang penyampaian materi relasi pada mata pelajaran matematika.

Analisis peserta didik, analisis peserta didik bertujuan untuk mengetahui kebutuhan peserta didik dalam pengembangan media pembelajaran berbantuan Macromedia Flash 8 berbasis kemaritiman. Peserta didik yang menjadi subjek penelitian adalah peserta didik kelas VIII C. Berdasarkan hasil wawancara tak terstruktur, peserta didik kurang memahami konsep terhadap materi relasi dan juga peserta didik kurang memiliki semangat belajar karena proses pembelajaran hanya sebatas penjelasan, tanya jawab dan latihan soal serta pemberian tugas. Mereka merasa bosan media yang digunakan tidak bervariasi.

Analisis konsep, analisis konsep ialah mengidentifikasi konsep media pembelajaran berbantuan Macromedia Flash 8 berbasis kemaritiman yang dikembangkan sesuai dengan Kompetensi Inti (KI), Komepetensi Dasar, dan Indikator.

b. Tahap Design

Tahap ini bertujuan untuk merancang media pembelajaran berbantuan Macromedia Flash 8 pada materi relasi kelas VIII SMP berbasis kemaritiman, terdiri dari beberapa tampilan dalam layar di antaranya halaman pembuka, halaman menu utama (petunjuk,KD dan tujuan pembelajaran, profil, materi dan evaluasi) pada Gambar 1.

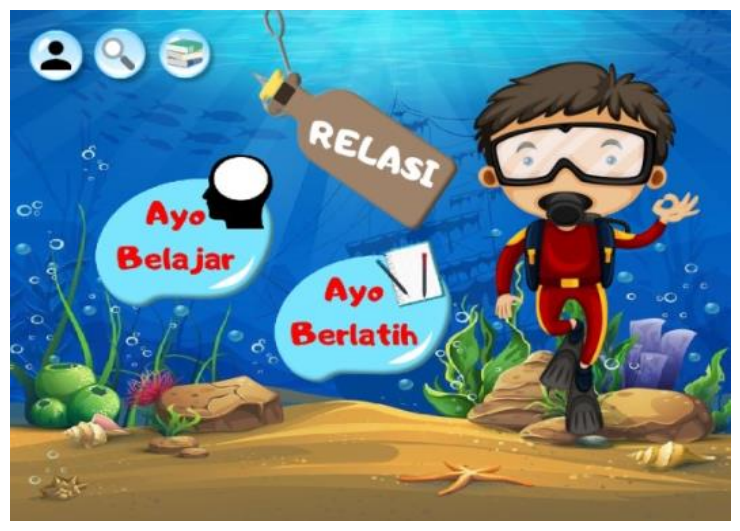

Gambar 1. Halaman utama media

Terdapat beberapa aplikasi pendukung untuk mendesain gambar-gambar yang akan digunakan dalam media yang dikembangkan diantaranya Pinterest, Canva dan Stickit!. Perancangan ini dideskripsikan dalam bentuk story board pada Gambar 2

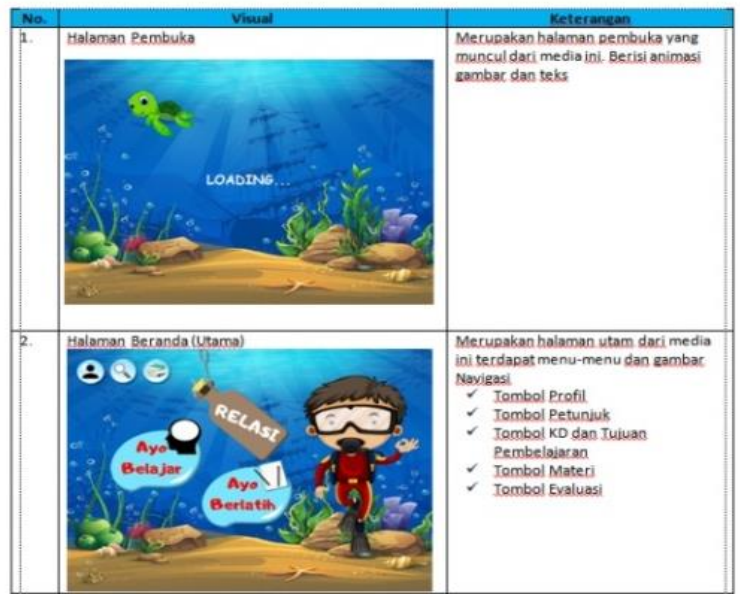

Gambar 2. Storyboard media pembelajaran 


\section{JURNAL GANTANG. Maret 2020; V(1): 87 - 93 \\ p-ISSN. 2503-0671 \\ e-ISSN. 2548-5547}

\section{c. Tahap Development}

Tahap ini bertujuan untuk menghasilkan media pembelajaran berbantuan Macromedia Flash 8 pada materi relasi kelas VIII SMP berbasis kemaritiman, melalui lembar instrumen dalam bentuk angket validasi oleh ahli media dan ahli materi. Aspek yang menjadi penilaian validasi media terdiri dari manfaat media, desain media, dan navigasi/pengoperasian media.

Hasil rekapitulasi hasil validasi media oleh ahli media diperoleh persentase rata-rata $91,25 \%$, sehingga dapat disimpulkan media pembelajaran yang dikembangkan menunjukkan kriteria interpretasi yang sangat layak dari segi media.

Selanjutnya dilakukan pemvalidasian oleh ahli materi. Dengan aspek yang menjadi penilaian validasi materi terdiri dari kesesuaian tujuan pembelajaran, kualitas materi, penyajian konten materi, dan penyajian self evaluation. Hasil rekapitulasi hasil validasi materi oleh ahli materi diperoleh persentase rata-rata 97,38\%, sehingga dapat disimpulkan media pembelajaran yang dikembangkan menunjukkan kriteria interpretasi yang sangat layak dari segi materi, dengan saran perbaikan dari ahli materi dipakai sebagai acuan perbaikan media pembelajaran yang dikembangkan.

Tabel 2.

Perbandingan media sebelum revisi dan sesudah revisi

Sebelum Revisi

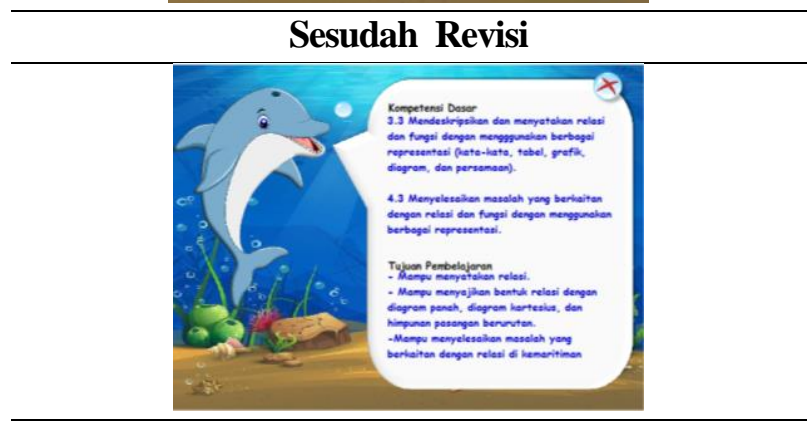

Saran ahli materi yaitu sebaiknya pada tujuan pembelajaran lebih ditekankan basis kemaritimannya
Adapun media pembelajaran yang telah divalidasi oleh ahli media dan ahli materi, maka diketahui hasil keseluruhan validasi adalah sebagai berikut.

Tabel 5.Rekapitulasi keseluruhan hasil validasi media dan materi

\begin{tabular}{llr}
\hline No. & Aspek Penilaian & Persentase \\
\hline 1. & Validasi Media oleh Ahli Media & $91,25 \%$ \\
2. & Validasi Media oleh Ahli Materi & $97,38 \%$ \\
\hline & Rata-rata Persentase & $\mathbf{9 4 , 3 2 \%}$ \\
\hline
\end{tabular}

Sumber: diolah oleh peneliti

Berdasarkan Tabel 5, bahwa hasil keseluruhan validasi diperoleh persentase 94,32\% dengan kriteria interpretasi sangat layak digunakan, dan dapat dilanjutkan untuk uji coba terbatas. Uji coba terbatas dilakukan pada bulan November 2019 di kelas VIII C SMP Negeri 3 Bintan dengan jumlah 26 peserta didik. Peneliti memberikan lembar angket respon peserta didik yang mencakup 11 pernyataan. Diperoleh ratarata persentasenya adalah $88,74 \%$ dengan kriteria interpretasi sangat layak. Sehingga dapat disimpulkan bahwa media yang dikembangkan melalui uji coba terbatas sangat layak digunakan.

\section{d. Tahap Disseminate}

Tahap disseminate, tahap ini dilakukan dengan cara mempromosikan produk pengembangan agar bisa diterima pengguna, baik individu, suatu kelompok atau sistem. Tahap ini dilakukan dengan menyebarluaskan produk yang telah dikembangkan. Produk disebarkan kepada calon pengguna dalam bentuk file melalui flashdisk ataupun Bluetooth.

\section{Kesimpulan}

Berdasarkan hasil keseluruhan proses pengembangan yang telah dilakukan diperoleh persentase kelayakan media dari hasil validasi ahli media sebesar 91,25\%, ahli materi sebesar 97,38\%, serta dari angket respon peserta didik sebesar $88,74 \%$, di mana ketiga penilaian tersebut termasuk kategori sangat layak. Dapat disimpulkan bahwa media pembelajaran animasi dengan nuansa kemaritiman berbantuan Macromedia Flash 8 pada materi relasi kelas VIII SMP sangat layak digunakan.

\section{Ucapan Terimakasih}

Artikel ini merupakan publikasi hasil penelitian bersama antara dosen dan mahasiswa. Peneliti 
mengucapkan terima kasih kepada semua pihak atas dukungannya terhadap kelancaran pelaksanaan penelitian ini.

\section{Referensi}

Azwar, S. (2009). Dasar-Dasar Psikometri (VIII). Yogyakarta: Pustaka Pelajar.

Daris, L. (2019). Kurikulum pendidikan berbasis maritim di era revolusi industri 4.0. Penguatan Pendidikan Karakter Di Era Revolusi Industri 4.0, 10.

Fatiris, N. (2017). Pengembangan media pembelajaran kartu uno pada kompetensi dasar menjelaskan sistem kearsipan untuk siswa kelas X Apk Di Smk Negeri 1 Surabaya. Jurnal Administrasi Perkantoran (JPAP), 5(2), 1-15.

Herawati, A. S. (2014). Kontruksi konsep relasi dan fungsi dalam sistem GUI MATLAB. Journal Matematika Universitas Jember, 2(November), 268-271.

Izzati, N. (2012). Peningkatan kemampuan komunikasi matematis dan kemandirian belajar siswa SMP melalui pendekatan matematika realistik. Universitas Pendidikan Indonesia.

Marsetio. (2018). Indonesia sebagai poros maritim dunia. Retrieved from http://dokumen.stimaimmi.ac.id/Orasi_Ilmi ah_IMMIi_cetak_A5.pdf

Mulyatiningsih, E. (2013). Metode terapan bidang pendidikan. Bandung: Alfabeta.

Muntaha, S., Budiman, M. A., \& Widyaningrum, A. (2019). Pengembangan media pembelajaran interaktif macromedia flash 8 pada pembelajaran tematik tema pengalamanku. International Journal of Elementary Education 3(2), 178-185.

Permendikbud No.65 Tahun 2013

Putra, T. A. (2018). Pengembangan media pembelajaran animasi berbasis macromedia flash pada materi trigonometri (Doctoral Dissertation), UIN Raden Intan Lampung, Lampung

Rosidah, I. D., \& Hasanah, U. (2019). Analisis problematika peserta didik pada mata pelajaran matematika materi relasi dan fungsi. Jurnal Penelitian Pendidikan Matematika (Snp2m) 2019 Umt, 56-62. 